\title{
Implementasi Algoritma Promethee II Pada Pemilihan Media Belajar Daring Di Era Pandemi Covid-19
}

\author{
Asep Syaputra ${ }^{[1]^{*}}$, Sasmita $^{[2]}$ \\ Program Studi Teknik Informatika ${ }^{[1],[2]}$ \\ Sekolah Tinggi Teknologi Pagaralam \\ Pagar Alam, Sumatera Selatan, Indonesia \\ asepsyaputra68@sttpagaralam.ac.id ${ }^{[1]^{*}}$, sasmita@sttpagaralam.ac.id ${ }^{[2]}$
}

\begin{abstract}
In order to support government policies to suppress the spread of COVID19, educational institutions are closed to faceto-face learning to support social distancing programs. Science and technology (IPTEK), especially information and communication technology (ICT), is growing very rapidly. These advances will inevitably affect all areas of life, including education. Only through the utilization of information and communication technology in the process of autonomy education and globalization of education can be successfully achieved. The trend of using online learning media from various circles of society has many functions, such as: news updates, communication tools, online learning and sharing (data, images, and sounds) without having to come face to face. The research aims to select the most popularly used learning media based on function, interest, or interface. This study uses the Promethee II method as an analysis of online media selection decisions with the results of calculations using ms. Excel 2019. Alternative criterion objects in this study use popular online learning media such as Zoom Meeting, E-Learning, Whatsapp, Youtube, and Google Classroom. This method uses the stages of data collection, namely survey methods, disseminating questionnaires to respondents to provide responses to the most popular and effective online learning media assessors.
\end{abstract}

Keywords- Promethee II, DSS, Online Learning

Abstrak-Dalam rangka mendukung kebijakan pemerintah untuk menekan penyebaran COVID19, institusi pendidikan diliburkan untuk belajar tatap muka guna mendukung program social distancing. Ilmu pengetahuan dan teknologi (IPTEK), khususnya teknologi informasi dan komunikasi (TIK), berkembang sangat pesat. Kemajuan ini pasti akan mempengaruhi semua bidang kehidupan, termasuk pendidikan. Hanya melalui pemanfaatan teknologi informasi dan komunikasi dalam proses pendidikan otonomi dan globalisasi pendidikan dapat berhasil dicapai. Tren penggunaan media belajar daring dari berbagai kalangan masyarakat memiliki banyak fungsi, seperti: update berita, alat komunikasi, belajar online dan berbagi (data, gambar, dan suara) tanpa harus bertatap muka. Penelitian ini bertujuan untuk memilih media belajar yang paling populer digunakan berdasarkan fungsi, minat, atau antarmuka. Penelitian ini menggunakan metode Promethee II sebagai analisis keputusan pemilihan media belajar online dengan hasil perhitungan menggunakan ms.Excel 2019. Objek kriteria alternatif dalam penelitian ini menggunakan media belajar online populer seperti Zoom Meeting, E-Learning, Whatsapp, Youtube, dan Google
Classroom. Penelitian Metode ini menggunakan tahapan pengumpulan data yaitu survey metode, menyebarkan kuesioner kepada responden untuk memberikan tanggapan terhadap penilai media belajar online paling popular dan efektif. Kata Kunci-Promethee II, DSS, Belajar Daring

\section{PENDAHULUAN}

Belajar adalah inti dari proses pendidikan. Mutu pendidikan menggambarkan kualitas pendidikan. Kualitas pendidikan dapat ditingkatkan dengan meningkatkan kualitas pengajaran [1]. Berbagai upaya telah dilakukan untuk peningkatan kualitas belajar. Teknologi informasi dan komunikasi (TIK) menawarkan berbagai kemungkinan untuk peningkatan kualitas pendidikan [2]. Teknologi dapat digunakan sebagai sumber dalam proses pembelajaran, sebagai alat bantu interaktif dalam proses pembelajaran, dan sebagai platform pembelajaran untuk meningkatkan dan mengembangkan keterampilan profesional guru [3]. TIK dapat mempromosikan dan mendukung pembelajaran siswa dan guru. TIK dapat digunakan untuk banyak tujuan: dari pasif untuk tujuan tampilan, pengumpulan informasi, interaksi dan komunikasi hingga yang paling aktif untuk pembuatan produk [4]. Era disrupsi teknologi informasi dan komunikasi (TIK) mempengaruhi segalanya. Dibidang pendidikan, dampak disrupsi TIK adalah pembelajaran online. Pembelajaran online mengacu pada pembelajaran yang tidak memerlukan komunikasi tatap muka antara guru dan siswa. Tapi ini terjadi secara online. Pelatihan dilakukan melalui video conference [5].

Pembelajaran online merupakan salah satu konsep dan teknologi di era 4.0. Teknologi ini menuntut guru dan dosen untuk berusaha menguasai dan mengoptimalkan aplikasi [6]. Di sisi lain, siswa juga perlu menguasainya yang banyak memakan tenaga dan biaya, karena berkaitan dengan waktu, biaya kuliah dan biaya internet yang harus mereka keluarkan dalam proses pembelajaran, termasuk kekuatan jaringan atau lokasi sinyal internet setiap murid [7]. Dengan ditiadakannya pembelajaran secara tatap muka karena penyebaran virus corona, belajar online menjadi solusi untuk mendukung proses belajar mengajar [8]. Selama pandemi, semakin banyak aplikasi pembelajaran online yang tersedia untuk dipilih [9]. Perubahan kebiasaan belajar ini membawa beberapa tantangan. Pergeseran 
dari metode belajar klaksial dan tatap muka ke metode pengajaran online telah menyebabkan tanggapan yang berbeda dari siswa [10].

Sistem online ini diharapkan siswa lebih terbantu dalam memperoleh ilmu dan pembelajaran tanpa harus berkunjung ke kampus. Sistem pembelajaran jarak jauh merupakan solusi untuk mengatasi kesulitan pengajaran tatap muka [11]. Namun, penerapan pembelajaran jarak jauh selama penyebaran pandemi Covid-19 menimbulkan banyak masalah [12]. Contoh masalah ini adalah guru dan siswa masih kesulitan untuk menggunakan aplikasi daring tersebut. Media belajar yang menyenangkan dan menarik dapat membantu menghilangkan kebosanan belajar. Belajar online membutuhkan perubahan tersendiri untuk menghilangkan kebosanan. Selain menggunakan media belajar yang menarik dalam perkuliahan online, kreativitas guru sangat penting dalam mempelajari cara menghindari kebosanan [13].

Penelitian ini merupakan pengembangan dari penelitian sebelumnya yang membahas Keputusan Penentuan Calon Penerima Beasiswa BBP- PPA Menggunakan Metode AHPPROMETHEE II, Nilai aktual atau akurasi AHPPROMETHEE II dalam mengidentifikasi calon penerima beasiswa BPP-PPA cukup tinggi karena mendekati pendapat ahli. Saat melakukan pemeringkatan menggunakan LF, ratarata akurasi sistem adalah $78 \%$. Pada saat yang sama, ketika peringkat menggunakan EF, akurasi rata-rata sistem adalah $85 \%$. Oleh karena itu, dapat disimpulkan bahwa pemeringkatan menggunakan EF dapat meningkatkan akurasi identifikasi calon penerima beasiswa BPP-PPA [14]. Penelitian selanjutnya membahas tentang Pemilihan Produk Conditioner Sebagai Upaya Peningkatan Minat Beli Konsumen menggunakan PROMETHEE II, penelitian ini menghasilkan keputusan dengan metode PROMETHEE II pada pemilihan produk conditioner sesuai dengan minat beli konsumen dapat diterapkan dimaan hasil menyimpulkan dari 4 alternatif yang direkomendasikan, produk conditioner Tresemme (A3) sebagai rekomendasi pertama dengan net flow 0.55 dan produk conditioner Sunslik (A2) sebagai rekomendasi kedua dengan net flow 0.35 [15].

Pada sistem pendukung keputusan yang menggunakan metode Promethee II untuk memilih perangkat pembelajaran online. Beberapa standar yang digunakan: interface, role, dan interest. Untuk menentukan perangkat pembelajaran interaktif yang banyak digunakan oleh pengguna, penelitian ini menyarankan pemilihan perangkat pembelajaran interaktif yang berbeda, seperti Google Classroom, Large Meeting, eLearning, WhatsApp, YouTube, dan Telegram. Perhitungan Promethee II ini digunakan untuk menentukan media pembelajaran online yang paling umum digunakan dan jejaring sosial yang paling sesuai dengan minat pengguna atau siswa.

Tujuan penelitian ini adalah menerapkan algoritma Promethee II pada pemilihan media belajar yang efektif dan sesuai dengan kegunaan dari media tersebut, algoritma Promethee II memiliki keunggulan terletak pada konsep logika matematika yang digunakan dalam pengembangan software DSS MCDM, secara teoritis dapat dikembangkan dengan menambahkan alternatif, standar dan bobot untuk menghasilkan solusi yang lebih akurat berdasarkan data multistandar dan lebih akurat.

\section{METODE PENELITIAN}

Metode penelitian dalam studi kasus pemilihan media sosial ini menggunakan pengumpulan dan pengolahan data. Tahapan pengumpulan dan pengolahan data adalah sebagai berikut:

\section{A. Promethee}

Multi criteria Decision Making (MCDM) telah menjadi salah satu bidang penelitian operasional dengan pertumbuhan tercepat selama dua dekade terakhir. Teori $M C D M$ sendiri dapat dibagi menjadi Multi Objective Decision Making (MODM) dan Multi Attribute Decision Making (MADM) [16]. MODM terus menganalisis subset dari ruang vektor, biasanya dibatasi oleh kendala, mengalokasikan semua solusi yang efisien, sebelum menentukan nilai optimal berdasarkan pilihan pengguna [17]. Oleh karena itu, MODM memungkinkan penggunaannya dalam perencanaan operasional, seperti perencanaan tujuan. MADM merupakan pendukung keputusan dengan input atribut/variabel yang berbeda. Dalam literatur teori keputusan, metode $M A D M$ diklasifikasikan berdasarkan informasi tertentu. Pada dasarnya metode ini membandingkan dua langkah matematis, yaitu mengumpulkan pertimbangan/evaluasi dengan menelaah setiap kriteria dan setiap alternatif serta mengurutkan alternatifalternatif tersebut menurut aturan pengumpulan. Dalam MADM memperhitungkan alternatif $\mathrm{A}$ dan $\mathrm{T}$ yang harus diklasifikasikan, serta kriteria K yang harus dioptimalkan [18].

$\mathrm{A}:=\{\mathrm{a} 1, \ldots \mathrm{aT}\}$.

$\mathrm{F}:=\{\mathrm{f} 1, \ldots \mathrm{fK}\}$.

Promethee adalah metode untuk menentukan urutan (prioritas) dalam MCDM. Masalah utama dengan metode ini adalah kesederhanaan, kejelasan dan stabilitas. Praduga dominasi kriteria yang digunakan dalam Promethee adalah penggunaan nilai dalam hubungan outclassing. Dalam metode ini, semua parameter yang dideklarasikan memiliki efek nyata dari sudut pandang ekonomi. Di Promethee ada enam bentuk fungsi preferensi kriteria. Meskipun tidak mutlak, bentukbentuk ini cukup baik untuk beberapa kasus [19].

Untuk memberikan gambaran yang lebih baik dari daerah yang tidak sama, digunakan perbedaan fungsi nilai kriteria antara alternatif $\mathrm{H}$ (d), dimana ini memiliki hubungan langsung dengan fungsi preferensi $\mathrm{P}$, seperti yang ditunjukkan pada persamaan (1).

$$
\left.\begin{array}{l}
\forall a, b \in A \\
f(a), f(b)
\end{array}\right\} \begin{aligned}
& f(a)>f(b) \Leftrightarrow a P b \\
& f(a)=f(b) \Leftrightarrow a I b
\end{aligned}
$$

\section{B. Perancangan Algoritma Perhitungan Metode Promethee}

Metode Promethee dalam perhitungan tes yang akan dilakukan melibatkan beberapa langkah yang harus diikuti [20]: 
1. Tentukan beberapa alternative

2. Tentukan beberapa kriteria

3. Menentukan tipe evaluasi dimana tipe evaluasi memiliki 2 tipe yaitu tipe minimal dan tipe maksimal.

4. Penentuan jenis preferensi untuk masing-masing kriteria yang paling sesuai didasarkan pada data dan pertimbangan pengambil keputusan.

5. Memberikan nilai threshold atau kecenderungan untuk setiap kriteria berdasarkan preferensi yang telah dipilih.

6. Perhitungan Entering Flow, Leaving Flow \& Net Flow.

7. Pengurutan hasil dari hasil pemeringkatan dimana pada metode promethee terdapat dua jenis pemeringkatan yaitu rangking parsial berdasarkan nilai Flow In dan Out dan rangking penuh/penuh berdasarkan nilai NetFlow.

\section{Metode Pengumpulan Data}

Metode pengumpulan data yang digunakan adalah data primer, dimana data diperoleh secara langsung dengan mengamati subjek survei yaitu penggunaan media belajar daring diberbagai kalangan. Penelitian ini menggunakan metode survei lapangan sebagai data utama dan mengirimkan kuesioner kepada responden. Langkah kedua adalah melakukan wawancara melalui pertanyaan dan jawaban langsung pengguna media belajar daring, serta mengumpulkan jawaban sesuai kriteria evaluasi yaitu dari segi tampilan, kesenangan dan kemudahan penggunaan. Langkah ketiga adalah mempelajari perpustakaan. Kegiatan ini termasuk mencari tautan ke data teoritis yang pada dasarnya terkait dengan penelitian yang sedang berlangsung, sehingga penelitian tersebut dibahas melalui penelitian kepustakaan, jurnal penelitian, bahan ajar, dan sumber pengetahuan lainnya [21].

Metode pengumpulan data dilakukan dengan menyebarkan kuesioner kepada 50 orang dari kelompok yang berbeda dengan menggunakan kategori responden yang ditunjukkan pada Tabel I. Lihat Tabel 2.

TABEL 1. DATA RESPONDEN

\begin{tabular}{|l|c|c|c|}
\hline \multicolumn{2}{|c|}{ Responden } & Jumlah & Persentase \\
\hline \multirow{3}{*}{ Usia } & $<12 \mathrm{Th}$ & 8 & $16 \%$ \\
\cline { 2 - 4 } & $12-20 \mathrm{Th}$ & 24 & $48 \%$ \\
\cline { 2 - 4 } & $>20 \mathrm{Th}$ & 18 & $36 \%$ \\
\hline \multirow{3}{*}{ Status } & Pelajar & 30 & $60 \%$ \\
\cline { 2 - 4 } & Umum & 20 & $40 \%$ \\
\hline \multicolumn{3}{|c|}{} \\
\hline
\end{tabular}

TABEL 2. DATA TANGGAPAN KUESIONER

\begin{tabular}{|l|c|c|c|}
\hline \multirow{2}{*}{ Uraian Pertanyaan } & Jawaban & Frekuensi & Persentase \\
& & & \\
\hline Media belajar daring & E-learning & 30 & $60 \%$ \\
yang anda gunakan! & Zoom meeting & 50 & $100 \%$ \\
(boleh lebih dari & Google classroom & 45 & $90 \%$ \\
satu) & Whatsapp & 20 & $40 \%$ \\
& Youtube & 18 & $36 \%$ \\
& Lainnya & 9 & $18 \%$ \\
& & & \\
\hline
\end{tabular}

\begin{tabular}{|c|c|c|c|}
\hline $\begin{array}{l}\text { Apa fungsi } \\
\text { penggunaan media } \\
\text { belajar daring? }\end{array}$ & $\begin{array}{c}\text { Komunikasi } \\
\text { Promosi }\end{array}$ & $\begin{array}{l}38 \\
12\end{array}$ & $\begin{array}{l}76 \% \\
24 \%\end{array}$ \\
\hline $\begin{array}{l}\text { Bagaimana tampilan } \\
\text { media belajar daring } \\
\text { menurut anda? }\end{array}$ & $\begin{array}{l}\text { Mudah dimengerti } \\
\text { Susah dimengerti }\end{array}$ & $\begin{array}{l}18 \\
32\end{array}$ & $\begin{array}{l}36 \% \\
64 \%\end{array}$ \\
\hline $\begin{array}{l}\text { Apakah anda } \\
\text { termasuk tipe yang } \\
\text { memiliki } \\
\text { keterbatasan } \\
\text { terhadap akses } \\
\text { internet? }\end{array}$ & $\begin{array}{c}\text { Iya } \\
\text { Tidak }\end{array}$ & $\begin{array}{l}11 \\
39\end{array}$ & $\begin{array}{l}22 \% \\
78 \%\end{array}$ \\
\hline
\end{tabular}

Tabel 2 merupakan rangkuman hasil angket yang memuat pertanyaan-pertanyaan kriteria evaluasi, meliputi antar muka, fungsi dan minat.

\section{Pengolahan Data}

Promethee II merupakan salah satu metode pemeringkatan atau penentuan prioritas Multi Criterion Decision Making $(M C D M)$, sehingga metode ini dikenal dengan konsepnya yang sederhana dan efektif [22]. Penggunaan promethee adalah untuk mengidentifikasi dan memutuskan berbagai alternatif. Langkah-langkah perhitungan metode Promethree II adalah sebagai berikut:

Promethee II memutuskan beberapa alternatif, dan kemudian membandingkan satu alternatif dengan yang lain (tatap muka) [23]. Alternatif tersedia untuk seleksi, Promethee II memulai pemeringkatan dengan memeriksa bahwa nilai aliran keluaran adalah nilai tertinggi dibandingkan dengan nilai data lainnya, dan nilai aliran udara adalah nilai terendah, sehingga ada prioritas data alternatif. Promethee II adalah produk Promethee dan termasuk NPV dalam proses klasifikasi [24].

Keuntungan dari metode promethee adalah mempertimbangkan beberapa ukuran pada saat yang sama, yang tidak mungkin dilakukan dengan proses pengambilan keputusan dasar yang umum hanya berdasarkan satu ukuran (ukuran yang berbeda dapat digunakan untuk setiap dimensi). Kelemahan dari metode promethee adalah jika didapatkan nilai parameter delta $=0$, maka metode promethee tidak dapat dijalankan. Untuk itu diberikanlah nilai delta yang $=0$ dan nilai $\mathrm{H}(\mathrm{d})=1$.

Ada enam (6) jenis/preferensi di Promethee: 1) Usual Criterion: preferensi mutlak untuk alternatif dengan nilai terbaik; 2) Quasi Criterion: penentuan nilai quasi (q) yang nantinya dijadkan acuan dalam pengambilan keputusan; 3) Uji linieritas: terlebih dahulu menilai kecenderungan nilai preferensi ( $\mathrm{p}$ ) yang digunakan dalam pengambilan keputusan; 4) Tingkat kriteria: Ada tiga (3) tingkat keputusan dalam proses pengambilan keputusan, yaitu preferensi lemah, mutlak baik dan buruk; 5) Kriteria linieritas: mempertimbangkan tren peningkatan linier dalam preferensi;

1. Melakukan Normalisasi

Langkah normalisasi matriks keputusan dilakukan dengan 
cara ini, yaitu nilai skala yang berbeda memiliki nilai baru dengan bobot skala yang sama, minimal 0 (nol), dan paling banyak 1 (satu). Normalisasi menggunakan persamaan berikut:

$$
\operatorname{Rij}=(X i j-\operatorname{Min}(X i j)) /(\operatorname{Max}(X j)-\operatorname{Min}(X j))
$$

\section{Dimana:}

$\mathrm{Rij}=$ nilai $\mathrm{i}$ dalam kriteria $\mathrm{j}$ yang ternormalisasi.

$\mathrm{Xij}=$ nilai lama alternatif $\mathrm{i}$ dalam kriteria $\mathrm{j}$.

$\operatorname{Min}(X j)=$ nilai min dalam kriteria $j$.

$\operatorname{Max}(X j)=$ nilai maks dalam kriteri $\mathrm{j}$.

2. Menemukan perbedaan alternatif/pasangan.

3. Pemilihan dan perhitungan fungsi preferensi.

Tentukan prevalensi standar. Saat membuat keputusan, pengambil keputusan harus menentukan bobot atau distribusi kriteria. Biaya preferensi dapat dihitung dengan menggunakan persamaan berikut:

$H(d)\left\{\begin{array}{l}0 \text { jika d }=0 \\ 0 \text { jika d } \leq 0 \\ 1 \text { jika d } \geq 0\end{array}\right.$

Keterangan:

$\mathrm{H}(\mathrm{d})=$ fungsi selisih kriteria antar alternatif

$\mathrm{d}=$ selisih nilai kriteria $\{\mathrm{d}=\mathrm{f}(\mathrm{a})-\mathrm{f}(\mathrm{b})\}$

4. Perhitungan nilai indeks preferensi.

Nilai fungsi preferensi yang sebelumnya diperoleh dari persamaan (1) kemudian dihitung ulang untuk mendapatkan indeks preferensi dengan beberapa kriteria (semua kriteria dalam substitusi). Berikut persamaan yang digunakan:

$$
(a, b)=\sum P i(a, b): \forall a, b \in A
$$

5. Menentukan Leaving flow dan Entering flow.

Perhitungan Leaving flow, yang jumlahnya dari arah mendekati simpul a disebut juga dengan jenis pengukuran outraking.

$$
\phi+(a)=1 n-1 \sum n=k(a, x)
$$

Perhitungan inflow, kuantitas memiliki arah dari node $a$ (dimensi atas).

$$
\phi-(a)=1 n-1 \sum n=k(a, x)
$$

6. Gunakan persamaan Net Flow berikut untuk mencari persamaan:

7. $(a)=\phi-(a)-\phi-(a)$

Jika nilai Entering Flow lebih tinggi dan nilai Leaving Flow lebih rendah, alternatif lebih mungkin dipilih, dan jika nilai $N e t$ Flow lebih tinggi, urutan yang lebih baik diadopsi.

\section{HASIL DAN PEMBAHASAN}

\section{A. Menentukan Alternatif}

Dengan semakin kompleksnya teknologi informasi modern, banyak alat pembelajaran online berkembang pesat. Dimasa pandemi saat ini, pengajaran tatap muka tidak memungkinkan, sehingga platform media pembelajaran online digunakan untuk proses pembelajaran dari yang terendah hingga yang tertinggi. Dari sudut pandang pembelajaran langsung, ini bertentangan dengan seruan untuk menjaga jarak fisik dan tinggal di rumah. Penggunaan perangkat pembelajaran online diberbagai kalangan sangat beragam, seperti komunikasi jarak jauh, pertukaran informasi, dan metode belajar mengajar. Tabel III memberikan beberapa contoh platform media alternatif pembelajaran online berdasarkan tren pengguna.

TABEL 3. ALTERNATIF KRITERIA

\begin{tabular}{|c|c|}
\hline Tren Media Belajar Daring & Kode \\
\hline Google Classroom & $\mathrm{A}$ \\
\hline Zoom Meeting & $\mathrm{B}$ \\
\hline E-Learning & $\mathrm{C}$ \\
\hline Whatssapp & $\mathrm{D}$ \\
\hline Youtube & $\mathrm{E}$ \\
\hline
\end{tabular}

\section{B. Menentukan Kriteria}

Kriteria penilaian perangkat pembelajaran online adalah antarmuka, fungsi, dan minat. Tabel 4 menunjukkan kriteria yang digunakan oleh responden untuk menilai perangkat pembelajaran online terpopuler berdasarkan frekuensi penggunaannya. Bisa dilihat di deskripsi sebagai berikut.

\begin{tabular}{|c|c|c|c|}
\hline \multicolumn{4}{|c|}{ TABEL 4. DATA KRITERIA } \\
\hline No & Uraian Kriteria & Bobot & Kode \\
\hline 1 & Interface & $20 \%$ & F1 \\
\hline 2 & Function & $40 \%$ & F2 \\
\hline 3 & Interest & $40 \%$ & F3 \\
\hline
\end{tabular}

\section{Implementasi Promethee II}

Analisis keputusan berdasarkan metode Promethee II menggunakan Ms. Excel 2019. Perhitungan manual ini digunakan untuk pengembangan website dan desktop, aplikasi mobile dan aplikasi DSS MCMD lainnya. Pertama, membandingkan data pengganti dengan kriteria yang diperoleh dari Tabel 2, yaitu. Kuesioner disebarkan sedemikian rupa

\begin{tabular}{|c|c|c|c|c|c|c|}
\hline \multirow{2}{*}{ No } & \multirow{2}{*}{ Kriteria } & \multicolumn{5}{|c|}{ Nilai Alternatif } \\
\hline & & $\mathbf{A}$ & B & $\mathbf{C}$ & D & $\mathbf{E}$ \\
\hline 1 & $\mathrm{~F} 1$ & 4 & 3 & 2 & 3 & 3 \\
\hline 2 & $\mathrm{~F} 2$ & 3 & 4 & 4 & 2 & 4 \\
\hline 3 & F3 & 4 & 4 & 4 & 3 & 3 \\
\hline \multicolumn{2}{|c|}{ Jumlah Nilai } & 11 & 11 & 10 & 8 & 10 \\
\hline
\end{tabular}
sehingga evaluasi setiap alternatif lingkungan sosial dilakukan sesuai dengan kriteria evaluasi yang ditunjukkan pada Tabel 5.

TABEL 5. DATA PENILAIAN

Bobot yang digunakan responden untuk menilai pentingnya alternatif (Media Belajar Daring) ditunjukkan pada Tabel 6. 
TABEL 6. TINGKAT KEPENTINGAN

\begin{tabular}{|c|c|}
\hline Bobot & Keterangan \\
\hline 5 & Sangat Baik \\
\hline 4 & Baik \\
\hline 3 & Cukup \\
\hline 2 & Kurang \\
\hline 1 & Sangat Kurang \\
\hline
\end{tabular}

IV. PEMBAHASAN

Pemilihan media pembelajaran online di era pandemi Covid19 dimodelkan menggunakan metode Promethee. Metode promethee ini digunakan sebagai dasar pengambilan keputusan berbasis pemeringkatan media pembelajaran online yang dijadikan sebagai alternatif. Pemodelan ini didasarkan pada kriteria dan parameter yang telah ditentukan sebelumnya. Dalam hal pemilihan media pembelajaran online di era pandemi Covid-19, kriteria yang digunakan antara lain Antarmuka, Fungsi, Minat. Selain kriteria yang ditentukan, perlu juga menentukan preferensi dari setiap kriteria dan parameternya.

Selain itu, setelah menentukan alternatif dan kriteria pemilihan, selanjutnya dimasukkan detail lokasi berdasarkan kriteria tersebut. Setelah itu, perhitungan prometheus dilakukan. Langkah-langkah dalam perhitungan prometheus ini mencari nilai outflow, inflow, dan net flow. Setelah mendapatkan arus bersih, dapat ditentukan urutan Media Pembelajaran Online yang trend positif di era pandemi covid19.

Setelah data mempunyai bobot nilai, langkah selanjutnya adalah:

1. Hitung selisih nilai antar alternatif berdasarkan kriteria tertentu.

Selisih nilai kriteria (d) dihitung dengan membandingkan alternatif satu dengan alternatif lain, atau alternatif a dikurangi nilai alternatif $b$, kemudian nilai fungsi preferensi $\mathrm{H}$ (d) dihitung menurut rumus berikut, dll Rumus (1).Tahap pertama ditunjukkan pada Tabel 7.

TABEL 7. BOBOT KRITERIA UNTUK SETIAP ALTERNATIF

\begin{tabular}{|c|c|c|c|c|c|}
\hline Alternatif & A & B & C & D & E \\
\hline \multirow{3}{*}{ A } & & $\mathrm{f} 1=1$ & $\mathrm{f} 1=1$ & $\mathrm{f} 1=1$ & $\mathrm{f} 1=1$ \\
& & $\mathrm{f} 2=0$ & $\mathrm{f} 2=0$ & $\mathrm{f} 2=1$ & $\mathrm{f} 2=0$ \\
$\mathrm{f} 3=1$ & $\mathrm{f} 3=0$ & $\mathrm{f} 3=1$ & $\mathrm{f}=1$ \\
\hline \multirow{3}{*}{ B } & $\mathrm{f} 1=1$ & & $\mathrm{f} 1=1$ & $\mathrm{f} 1=0$ & $\mathrm{f} 1=0$ \\
& $\mathrm{f} 2=0$ & & $\mathrm{f} 2=0$ & $\mathrm{f} 2=1$ & $\mathrm{f} 2=0$ \\
& $\mathrm{f} 3=1$ & & $\mathrm{f} 3=0$ & $\mathrm{f} 3=1$ & $\mathrm{f} 3=1$ \\
\hline \multirow{3}{*}{ C } & $\mathrm{f} 1=0$ & $\mathrm{f} 1=0$ & & $\mathrm{f} 1=0$ & $\mathrm{f} 1=0$ \\
& $\mathrm{f} 2=1$ & $\mathrm{f} 2=0$ & & $\mathrm{f} 2=1$ & $\mathrm{f} 2=0$ \\
& $\mathrm{f} 3=0$ & $\mathrm{f} 3=0$ & & $\mathrm{f} 3=1$ & $\mathrm{f} 3=1$ \\
\hline \multirow{3}{*}{ D } & $\mathrm{f} 1=0$ & $\mathrm{f} 1=0$ & $\mathrm{f} 1=1$ & & $\mathrm{f} 1=0$ \\
& $\mathrm{f} 2=0$ & $\mathrm{f} 2=0$ & $\mathrm{f} 2=0$ & & $\mathrm{f} 2=1$ \\
& $\mathrm{f}=0$ & $\mathrm{f} 3=0$ & $\mathrm{f} 3=0$ & & $\mathrm{f} 3=0$ \\
\hline \multirow{2}{*}{ E } & $\mathrm{f} 1=0$ & $\mathrm{f} 1=0$ & $\mathrm{f} 1=1$ & $\mathrm{f} 1=0$ & \\
& $\mathrm{f} 2=1$ & $\mathrm{f} 2=0$ & $\mathrm{f} 2=0$ & $\mathrm{f} 2=1$ & \\
& $\mathrm{f} 3=0$ & $\mathrm{f} 3=0$ & $\mathrm{f} 3=0$ & $\mathrm{f} 3=0$ & \\
\hline
\end{tabular}

2. Hitung nilai indeks preferensi

Nilai indeks preferensi diperoleh dari fungsi preferensi ratarata tertimbang pada Tabel 8. Dihitung dengan membagi nilai standar setiap alternatif yang diperoleh pada Tabel 8 dengan angka standar, dan hasilnya adalah nilai indeks preferensi alternatif. Tabel 8 menunjukkan hasil keseluruhan indeks preferensi substitusi.

TABEL 8. INDEKS PRESENSI

\begin{tabular}{|c|c|c|c|c|c|}
\hline Alternatif & $\mathbf{A}$ & $\mathbf{B}$ & $\mathbf{C}$ & $\mathbf{D}$ & $\mathbf{E}$ \\
\hline $\mathbf{A}$ & & 0,66 & 0,33 & 1 & 0,66 \\
\hline $\mathbf{B}$ & 0,33 & & 0,33 & 0,33 & 0,33 \\
\hline $\mathbf{C}$ & 0,33 & 0 & & 0,66 & 0,33 \\
\hline $\mathbf{D}$ & 0 & 0 & 0,33 & & 0,33 \\
\hline $\mathbf{E}$ & 0,33 & 0 & 0,33 & 0,33 & \\
\hline
\end{tabular}

3. Hitung Leaving Flow

Gunakan persamaan (3) untuk menghitung jumlah data dengan perkiraan arah simpul $a$ setelah memilih aliran keluaran dari lingkungan pembelajaran online.

$$
\text { A } \begin{aligned}
\phi+(a) & =1 / 5-1(0.66+0.33+1+0.66) \\
& =0.25 * 2.66 \\
& =0.66 \\
\text { B } \phi+(a) & =1 / 5-1(0.33+0.33+0.66+0.33) \\
& =0.25 * 1.66 \\
& =0.41 \\
\text { C } \phi+(a) & =1 / 5-1(0.33+0+0.66+0.33 \\
& =0.25 * 1.33 \\
& =0.33 \\
\text { D } \phi+(a) & =1 / 5-1(0+0+0.33+0.33) \\
& =0.25 * 0.66 \\
& =0.16 \\
\text { E } \phi+(a) & =1 / 5-1(0.33+0+0.33+0.33) \\
& =0.25 * 1 \\
& =0.25
\end{aligned}
$$

4. Hitung Entering Flow

Perhitungan pada tahap ini menggunakan persamaan (4), dimana jumlah data yang alamatnya jauh dari node a disebut overshoot.

$$
\text { A } \begin{aligned}
\phi-(a) & =1 / 5-1(0.33+0.33+0+0.33) \\
& =0.25^{*} 1 \\
& =0.25 \\
\text { B } \phi-(a) & =1 / 5-1(0.66+0+0+0) \\
& =0.25^{*} 0.66 \\
& =0.16 \\
\text { C } \phi-(a) & =1 / 5-1(0.33+0.33+0.33+0.33) \\
& =0.25 * 1.33 \\
& =0.33 \\
\text { D } \phi-(a) & =1 / 5-1(1+0.66+0.66+0.33) \\
& =0.25^{*} 3 \\
& =0.66 \\
\text { E } \phi-(a) & =1 / 5-1(0.66+0.66+0.66+0.33) \\
& =0.25^{*} 1.66 \\
& =0.41
\end{aligned}
$$


5. Hitung Net Flow

Net Flow diperoleh dengan mengurangkan Net Flow masuk dari nilai aliran menurut persamaan (5). Tahap Clean Flow merupakan tahap akhir dari proses Promethee II, dimana hasil Clean Flow adalah nilai klasifikasi yang ditunjukkan pada Tabel 9.

$$
\begin{aligned}
& \phi(a)=(0.66-0.25)=0.42 \\
& \phi(a)=(0.41-0.16)=0.25 \\
& \phi(a)=(0.33-0.33)=0 \\
& \phi(a)=(0.16-0.66)=-0.50 \\
& \phi(a)=(0.25-0.41)=-0.17
\end{aligned}
$$

TABEL 9. RANGKING MEDIA BELAJAR DARING

\begin{tabular}{|c|c|c|c|c|}
\hline Alternatif & $\begin{array}{c}\text { Leaving } \\
\text { Flow }\end{array}$ & $\begin{array}{c}\text { Entring } \\
\text { Flow }\end{array}$ & Net Flow & Rangking \\
\hline Google Classroom & 0.66 & 0.25 & 0.42 & 1 \\
\hline Zoom Meeting & 0.41 & 0.16 & 0.25 & 2 \\
\hline E-Learning & 0.33 & 0.33 & 0 & 3 \\
\hline Whatssapp & 0.25 & 0.41 & -0.17 & 4 \\
\hline Youtube & 0.16 & 0.66 & -0.50 & 5 \\
\hline
\end{tabular}

\section{KESIMPULAN}

Berdasarkan penelitian di atas, dapat dijelaskan bahwa metode Promethee II dapat diterapkan pada sistem pendukung keputusan untuk memilih perangkat pembelajaran online bagi pengguna perangkat pembelajaran online populer saat ini. Antarmuka pengguna, fungsionalitas, dan minat dalam berbagai alternatif alat pembelajaran online, termasuk Google Classroom, Zoom Meeting, E-Learning, WhatsApp, YouTube. Menurut perhitungan berdasarkan metode Promethee II, hasil pemeringkatan media pembelajaran online yang paling umum dan efektif digunakan adalah media Google Classroom yang memperoleh nilai 0,42 dari 50 responden/pengguna dari berbagai kalangan.

\section{REFERENCES}

[1] A. Syaputra, "Aplikasi E-Kelurahan Untuk Peningkatan Pelayanan Administrasi Dalam Mendukung Penerapan E-Government," MATRIK J. Manajemen, Tek. Inform. dan Rekayasa Komput., vol. 20, no. 2, pp. 379-388, 2021.

[2] A. Syaputra, "Pelatihan Maintenance Komputer Pada Himpunan Mahasiswa Teknik Informatika Kota Pagar Alam,” NGABDIMAS, vol. 3, no. 2, pp. 75-81, 2020.

[3] D. Novita and A. R. Hutasuhut, "Plus Minus Penggunaan Aplikasi Aplikasi Pembelajaran Daring Selama Pandemi Covid 19," Unimed Medan, June, pp. 1-11, 2020.

[4] A. Syaputra, "Sistem Monitoring Prestasi Akademik Siswa Pada Sekolah Menengah Atas Negeri 5 Pagar Alam," Jurnal. ilmiah. Inform., vol. 5, no. 2, pp. 76-84, 2020.

[5] C. Riyana and M. Pd, "Konsep pembelajaran online," Modul Pembelajaran On-Line, vol. 1, 2020.
[6] F. Ahmadi and H. Ibda, Konsep dan aplikasi literasi baru di era revolusi industri 4.0 dan society 5.0. CV. Pilar Nusantara, 2019.

[7] H. S. Zainiyati, Pengembangan Media Pembelajaran Agama Islam Berbasis ICT. Kencana, 2017.

[8] A. Hasanah, A. S. Lestari, A. Y. Rahman, and Y. I. Daniel, "Analisis aktivitas belajar daring mahasiswa pada pandemi Covid-19,” 2020.

[9] M. S. Ulum and J. Pamungkas, "Analisis Kritis Penerapan Metode Pembelajaran Berbasis Online di Madrasah Ibtidaiyah Masa Pandemi COVID 19 (Solusi Menyelamatkan Masa Depan Anak-Anak Indonesia)," MUBTADI J. Pendidik. Ibtidaiyah, vol. 2, no. 1, pp. $17-$ $35,2020$.

[10] A. D. Samala, B. R. Fajri, and F. Ranuharja, "Desain Dan Implementasi Media Pembelajaran Berbasis Mobile Learning Menggunakan Moodle Mobile App," J. Teknol. Inf. Dan Pendidik., vol. 12, no. 2, pp. 13-20, 2019.

[11] S. Suprapno et al., "TANTANGAN PENDIDIKAN DI MASA PANDEMI COVID-19." CV. Literasi Nusantara Abadi, 2021.

[12] A. Sholeh, "Implementasi Pendekatan Home Visit Upaya Mengatasi Problematika Pembelajaran Daring pada Siswa Sekolah Dasar Di Masa Pandemic Covid-19," J. Bid. Pendidik. Dasar, vol. 5, no. 1, pp. $80-89,2021$.

[13] H. Susanto and H. Akmal, "Media Pembelajaran Sejarah Era Teknologi Informasi (Konsep Dasar, Prinsi Aplikatif, dan Perancangannya)." FKIP Universitas Lambung Mangkurat, 2019.

[14] N. N. Satriani, I. Cholissodin, and M. A. Fauzi, "Sistem Pendukung Keputusan Penentuan Calon Penerima Beasiswa BBP-PPA Menggunakan Metode AHP-PROMETHEE I Studi Kasus: FILKOM Universitas Brawijaya," J. Pengemb. Teknol. Inf. dan Ilmu Komput. e-ISSN, vol. 2548, p. 964X, 2018.

[15] D. N. Batubara, A. P. Windarto, and M. R. Raharjo, "Penerapan Promethee II Pada Pemilihan Produk Conditioner Sebagai Upaya Peningkatan Minat Beli Konsumen," CESS (Journal Comput. Eng. Syst. Sci., vol. 4, no. 2, pp. 191-197, 2019.

[16] S. Mujilahwati, N. Q. Nawafilah, and M. Aliyudin, "Analisis Hasil Prediksi dengan Metode Promethee," Mnemon. J. Tek. Inform., vol. 2, no. 1, pp. 35-40, 2019.

[17] F. R. Umbara, B. Rosidharta, M. B. Chaniago, S. Chintia, D. F. Hasanah, and I. Rijayana, "Adiyasa Nurfalah, Adiwijaya, Arie Ardiyanti Suryani."

[18] A. P. LARASATI, "Pemilihan material untuk perancangan produk menggunakan metode topsis pada UPT Ragam Metal Yogyakarta." UAJY, 2017.

[19] J. Karim, "Sistem Pendukung Keputusan Penentuan Prioritas Pembangunan Menggunakan Metode Promethee Pada Desa Ayula Kecamatan Randangan Kabupaten Pohuwato Provinsi Gorontalo," Ilk. J. Ilm., vol. 10, no. 1, pp. 86-91, 2018.

[20] S. Pami, "Sistem Pendukung Keputusan Pemilihan Karyawan Terbaik Dengan Metode Promethee (Studi Kasus: PT. Karya Abadi Mandiri)," Pelita Inform. Inf. dan Inform., vol. 6, no. 1, pp. 125-128, 2017.

[21] A. Syaputra, "Kombinasi Metode AHP dan TOPSIS dalam Pemilihan Bibit Sayuran Berdasarkan Kondisi Tanah dan Syarat Tumbuh Tanaman," J. Ilm. Inform., vol. 6, no. 1, pp. 11-19, 2021.

[22] G. A. Muhammad, "Penerapan Five Factor Model (FFM) Dan Technique For Oder Preference By Similarity To Ideal Solution (TOPSIS) Pada Pemilihan Tenaga Kerja.(Studi Kasus: PT. X)." Institut Teknologi Sepuluh Nopember, 2018.

[23] H. Harmayani and V. Dwina, "Analisis Metode Multi Factor Evaluation Process pada Pemilihan Produk Perbankan yang sesuai Kebutuhan Nasabah," J-SAKTI (Jurnal Sains Komput. dan Inform., vol. 4, no. 2, pp. 711-720, 2020

[24] E. Fitriani, "Perbandingan Algoritma C4. 5 Dan Naïve Bayes Untuk Menentukan Kelayakan Penerima Bantuan Program Keluarga Harapan,” Sist. J. Sist. Inf., vol. 9, no. 1, pp. 103-115, 2020. 